\title{
Teaching NeuroImages: Facial swelling and intracerebral hemorrhage from venous hypertension in a dialysis patient
}

Ekaterina Bakradze, MD, Richard L. Zampolin, MD, Yosef S. Golowa, MD, Deepa Bhupali, MD, David D. Pasquale, MD, and Ava L. Liberman, MD

Neurology ${ }^{\circledR}$ 2019;92:e521-e522. doi:10.1212/WNL.0000000000006860

Figure 1 Ipsilateral facial swelling in a patient with intracerebral hemorrhage

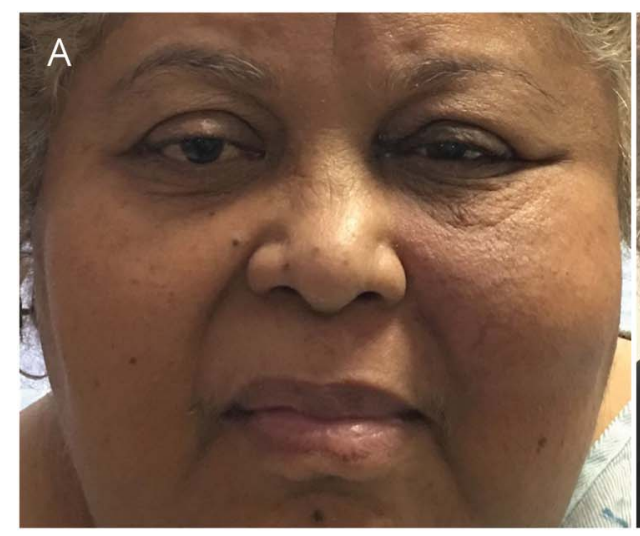

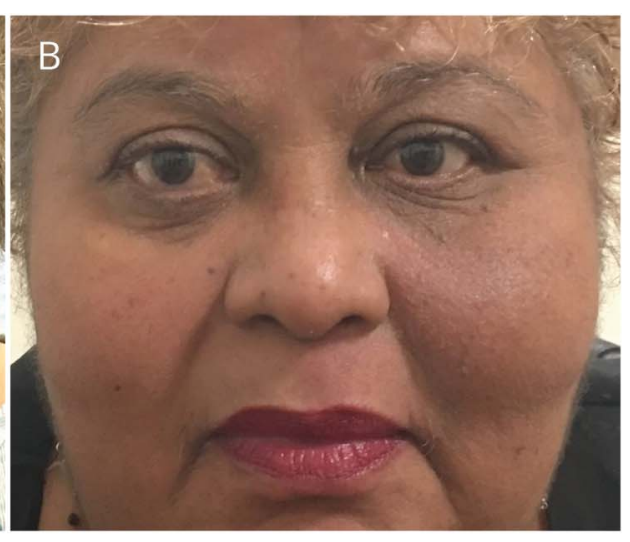

Left facial swelling (A) before and (B) 6 weeks after venous recanalization.

A 56-year-old woman on hemodialysis through left arm arteriovenous fistula presented with headache, aphasia, and gradually worsening left facial swelling (figure 1A). MRI showed left temporal intracerebral hemorrhage with arterialized veins (figure 2, A and B). Cerebral angiography revealed multiple areas of venous flow reversal suggesting venous hypertension (figure 2C). Fistulogram demonstrated chronic left cephalic vein occlusion with outflow retrograde through the left internal jugular, facial, intracranial, and then centrally through right internal jugular veins. Recanalization of the venous occlusion improved facial swelling (figure 1B). Early recognition of facial swelling may prevent intracerebral hemorrhage in patients with arteriovenous fistula. $^{1,2}$

\section{Study funding}

No targeted funding reported.

\section{Disclosure}

E. Bakradze is supported by U10 NS08653. R. Zampolin, Y. Golowa, D. Bhupali, D. Pasquale, and A. Liberman report no disclosures relevant to the manuscript. Go to Neurology.org/ $\mathrm{N}$ for full disclosures.

From the Departments of Neurology (E.B., A.L.L.), Radiology (R.L.Z.), and Vascular \& Interventional Radiology (Y.S.G.), Montefiore Medical Center, Albert Einstein College of Medicine, Bronx, NY; Department of Neurology and Rehabilitation (D.B.), University of Illinois at Chicago; and Intellirad Imaging (D.D.P.), Kendall Regional Medical Center, Miami, FL. 
Figure 2 Left temporal hemorrhage with arterialized veins
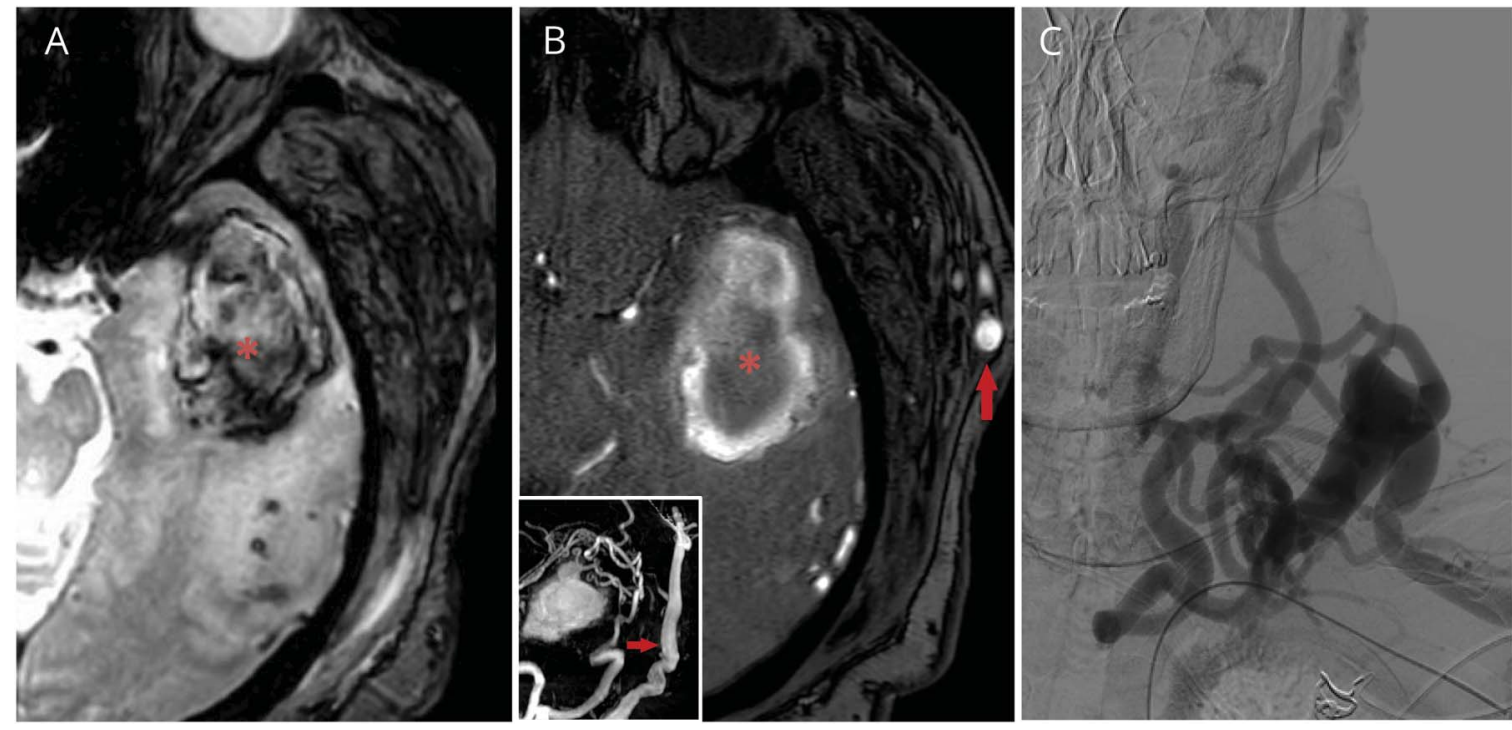

(A) Gradient echo image shows acute left temporal hemorrhage (asterisk). (B) MRA of the head shows a large left temporal intracerebral hemorrhage (asterisk) and arterialized veins, including the left superficial temporal vein (arrows). (C) Network of abnormal veins in the left neck derived from the left cephalic, subclavian, and internal jugular veins due to proximal venous occlusion.

\begin{tabular}{|c|c|c|c|}
\hline Name & Location & Role & Contribution \\
\hline $\begin{array}{l}\text { Ekaterina } \\
\text { Bakradze, } \\
\text { MD }\end{array}$ & $\begin{array}{l}\text { Montefiore } \\
\text { Medical Center, } \\
\text { New York }\end{array}$ & Author & $\begin{array}{l}\text { Designed and } \\
\text { conceptualized the study; } \\
\text { drafted the manuscript for } \\
\text { intellectual content }\end{array}$ \\
\hline $\begin{array}{l}\text { Richard L. } \\
\text { Zampolin, } \\
\text { MD }\end{array}$ & $\begin{array}{l}\text { Montefiore } \\
\text { Medical Center, } \\
\text { New York }\end{array}$ & Author & $\begin{array}{l}\text { Major role in acquisition of } \\
\text { data }\end{array}$ \\
\hline $\begin{array}{l}\text { Yosef S. } \\
\text { Golowa, } \\
\text { MD }\end{array}$ & $\begin{array}{l}\text { Montefiore } \\
\text { Medical Center, } \\
\text { New York }\end{array}$ & Author & $\begin{array}{l}\text { Major role in acquisition of } \\
\text { data }\end{array}$ \\
\hline $\begin{array}{l}\text { Deepa } \\
\text { Bhupali, } \\
\text { MD }\end{array}$ & $\begin{array}{l}\text { University of } \\
\text { Illinois at Chicago }\end{array}$ & Author & $\begin{array}{l}\text { Revised the manuscript for } \\
\text { intellectual content }\end{array}$ \\
\hline $\begin{array}{l}\text { David D. } \\
\text { Pasquale, } \\
\text { MD }\end{array}$ & $\begin{array}{l}\text { Kendall Regional } \\
\text { Medical Center, } \\
\text { Miami, FL }\end{array}$ & Author & $\begin{array}{l}\text { Revised the manuscript for } \\
\text { intellectual content }\end{array}$ \\
\hline $\begin{array}{l}\text { Ava L. } \\
\text { Liberman }\end{array}$ & $\begin{array}{l}\text { Montefiore } \\
\text { Medical Center, } \\
\text { New York }\end{array}$ & Author & $\begin{array}{l}\text { Interpreted the data and } \\
\text { revised the manuscript for } \\
\text { intellectual } \\
\text { content }\end{array}$ \\
\hline
\end{tabular}

\section{References}

1. Hartmann A, Mast H, Stapf C, Koch HC, Marx P. Peripheral hemodialysis shunt with intracranial venous congestion. Stroke 2001;32:2945-2946.

2. Prasad V, Baghai S, Gandhi D, Moeslein F, Jindal G. Cerebral infarction due to central vein occlusion in a hemodialysis patient. J Neuroimaging 2015;25:494-496. 


\section{Neurology}

\section{Teaching NeuroImages: Facial swelling and intracerebral hemorrhage from venous hypertension in a dialysis patient}

Ekaterina Bakradze, Richard L. Zampolin, Yosef S. Golowa, et al.

Neurology 2019;92;e521-e522

DOI 10.1212/WNL.0000000000006860

This information is current as of January 28, 2019

\section{Updated Information \&} Services

References

Subspecialty Collections

Permissions \& Licensing

Reprints including high resolution figures, can be found at: http://n.neurology.org/content/92/5/e521.full

This article cites 2 articles, 1 of which you can access for free at: http://n.neurology.org/content/92/5/e521.full\#ref-list-1

This article, along with others on similar topics, appears in the following collection(s):

Intracerebral hemorrhage

http://n.neurology.org/cgi/collection/intracerebral_hemorrhage

Information about reproducing this article in parts (figures,tables) or in its entirety can be found online at:

http://www.neurology.org/about/about_the_journal\#permissions

Information about ordering reprints can be found online:

http://n.neurology.org/subscribers/advertise

Neurology ${ }^{\circledR}$ is the official journal of the American Academy of Neurology. Published continuously since 1951, it is now a weekly with 48 issues per year. Copyright (O 2019 American Academy of Neurology. All rights reserved. Print ISSN: 0028-3878. Online ISSN: 1526-632X.

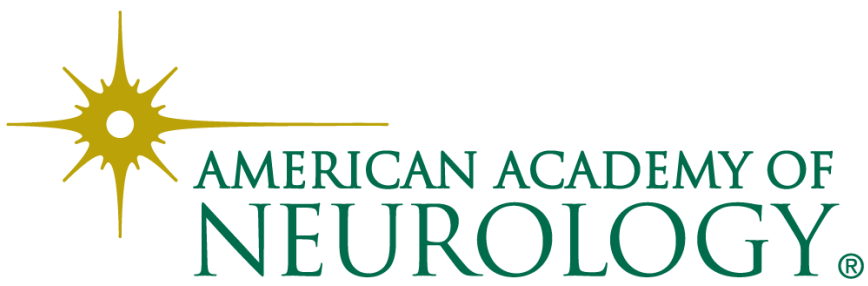

